\title{
Review
}

\section{Nutraceutical production by propionibacteria}

\author{
Jeroen Hugenholtz a,b*, Jan Hunik ${ }^{\mathrm{c}}$, Helena SAntos ${ }^{\mathrm{d}}$, Eddy SMID ${ }^{\mathrm{a}}$
}

\author{
${ }^{\text {a }}$ NIZO Food Research, PO Box 20, 6710 BA, Ede, The Netherlands \\ ${ }^{\mathrm{b}}$ Wageningen Centre for Food Sciences, PO Box 557, 6700 AN Wageningen, The Netherlands \\ ${ }^{c}$ DSM Food Specialties, PO Box 1, 2600 MA Delft, The Netherlands \\ d Instituto de Biologica Experimental e Technologica, Oeiras, Portugal
}

\begin{abstract}
Propionibacteria are able to produce a wide variety of food components that are benificial to the human health. First of all, because of its unique metabolism, Propionibacterium contains a wide variety of co-factors, mainly involved in transfer and rearrangement of $\mathrm{C} 1$-compounds. This microorganism has been known for decades as an efficient vitamin $\mathrm{B}_{12}$ (deoxy adenosyl cobalamin) producer. In this contribution, a new fermentation strategy is described leading to fermentation broths with high levels of this vitamin. In addition, some strains within the Propionibacterium genus can produce large amounts of folic acid. Other potential beneficial or nutritional ingredients produced by these bacteria are anti-microbial compounds such as propionic acid and bacteriocins. Propionic acid is reported to have potent growth-inhibiting effects on fungi and as such the Propionibacterium fermentation has great potential in food preservation. In addition, several bacteriocins have been found to be produced by these bacteria such as propionicin PLG-1 and jenseniin $G$, acting against a variety of $\operatorname{Gram}(+)$ bacteria. Finally, the production of high (intracellular) levels of the low-calorie sugar trehalose is reported. This sugar, presumably, functions as compatible solute in this bacterium and certain strains accumulate huge amounts under selected conditions. The possibility for application of this metabolism are discussed.
\end{abstract}

\section{Propionibacterium / folate / vitamin $\mathrm{B}_{12}$ / trehalose / antimicrobial}

Résumé — Production de nutraceutiques par les bactéries propioniques. Les bactéries propioniques sont capables de produire une grande variété de composés alimentaires bénéfiques pour la santé humaine. En premier lieu, en raison de son métabolisme unique, Propionibacterium contient une grande variété de co-facteurs, principalement impliqués dans le transfert et le réarrangement de composés $\mathrm{C} 1$. Ce microorganisme a été reconnu depuis des décennies comme producteur efficace de vitamine $\mathrm{B}_{12}$ (deoxy adenosyl cobalamine). Dans cet article, une nouvelle stratégie de fermentation est décrite conduisant à des bouillons de fermentation avec des niveaux élevés de cette vitamine. De plus,

Oral communication at the 3rd International Symposium on Propionibacteria, Zurich, Switzerland, July 8-11, 2001.

* Correspondence and reprints

Tel.: (31) 318659 540; fax: (31) 318650 400; e-mail: hugenhol@nizo.nl 
certaines souches dans le genre Propionibacterium peuvent produire de grandes quantités d'acide folique. D'autres ingrédients potentiellement bénéfiques ou nutritionnels produits par ces bactéries sont des composés anti-microbiens comme l'acide propionique et les bactériocines. L'acide propionique est décrit pour avoir des effets puissants d'inhibition de la croissance fongique, et de ce fait, la fermentation de Propionibacterium a de grandes potentialités en conservation des aliments. De plus, plusieurs bactériocines sont produites par ces bactéries telles que la propionicine PLG-1 et la jenseniine $\mathrm{G}$, actives contre plusieurs bactéries Gram $(+)$. Enfin, la production de niveaux élevés (intracellulaires) de tréhalose, sucre peu calorique, a été décrite. Ce sucre, probablement, fonctionne comme soluté compatible dans cette bactérie, et certaines souches accumulent de quantités très élevées sous certaines conditions. La possibilité d'application de ce métabolisme est discutée.

Propionibacterium / folate / vitamine $\mathbf{B}_{12}$ / tréhalose / composé antimicrobien / bactériocine

\section{INTRODUCTION}

The term "Nutraceuticals", launched by Stephen DeFelice in the 1980's, defines a wide range of foods and food components with a claimed medical or health benefit. An increasing number of food components are being labeled "nutraceuticals", often without proper scientific basis. In this overview, the term nutraceutical is used in its original meaning and the focus is only on food components produced by or foods fermented by propionibacteria with clearly proven health benefits.

The health-promoting foods or food components targeted in this overview can be categorised into three groups:

1. B-vitamins such as folic acid (vitamin $\mathrm{B}_{11}$ ) and vitamin $\mathrm{B}_{12}$.

2. Antimicrobial compounds such as propionic acid and bacteriocins.

3. No- or low-calorie sugars such as trehalose.

The levels of these three groups of food components can be enhanced in food and feed through fermentation using propionibacteria. Alternatively, the propionibacteria can be used as cell-factory for the production of these nutraceuticals as food ingredients. Several examples of in situ production of nutraceuticals and the use of these bacteria as nutraceutical cell-factory will be discussed in this overview.

\section{VITAMIN PRODUCTION}

Propionibacteria are known for there unique, anaerobic, metabolism involving several carbon rearrangement reactions. To catalyse these reactions, the propionibacteria contain a wide variety of enzymes with specific cofactors involved in these rearrangements, such as coenzyme $B_{12}$ (deoxyadenosylcobalamin), folic acid and biotin. Propionibacteria have long been known for their high production of vitamin $\mathrm{B}_{12}$ and this has led to the development of commercially interesting production processes. In this overview we also discuss the possibility of using propionibacteria for the production of another B-vitamin, folic acid.

\subsection{Vitamin $B_{12}$}

Vitamin $B_{12}$ is an essential vitamin in the human diet. The daily requirement of this vitamin for an average adult is about $3 \mu \mathrm{g}$ per day [34, 37]. Malnutrition on the level of vitamin $\mathrm{B}_{12}$-intake can lead to several physiological disorders, most notably anemia. Only two $\mathrm{B}_{12}$-dependent reactions have been identified in humans, methionine synthetase and methyl malonyl CoA mutase, involved in lipid turnover [37]. In many bacteria, $\mathrm{B}_{12}$ serves as cofactor in many different carbon rearrangement reactions as occur during breakdown of amino acids or metabolism of small carbon 


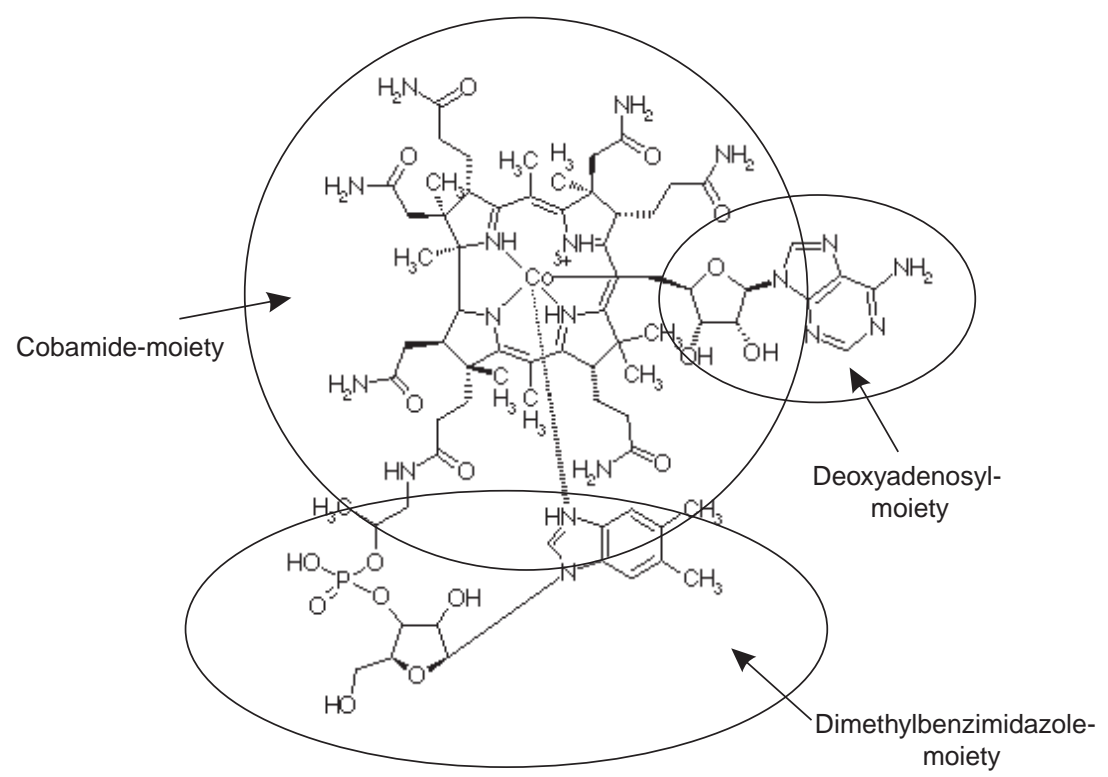

Figure 1. Structure of co-enzyme $B_{12}$ showing the three different moieties - dimethylbenzimidazole, cobamide and deoxyadenosyl.

molecules such as glycerol, ethanolamine and propionic acid.

There are, currently, only three microorganisms used for commercial production of vitamin $\mathrm{B}_{12}$, namely Pseudomonas denitrificans, Bacillus megaterium and Propionibacterium [21, 23, 37]. The dairy type of Propionibacterium has the huge advantage that they are food-grade and vitamin $B_{12}$ can be produced in the food, or added to the food, without the need for elaborate processing. Microorganisms produce coenzyme $\mathrm{B}_{12}$ or deoxyadenosylcobalamin (Fig. 1) via a complicated pathway involving at least 25 conversion steps from the starting precursors uroporphyrinogen III precursor for heme, F430 and cobalamin dimethylbenzimidazole and a adenosylmoiety. The biosynthesis of the precursor uropophyrinogen III, itself, involves a multistep pathway from the amino acid aminolevulenic acid via porphobilinogen to uroporphyrinogen III. The synthesis of dimethylbenzimidazole has not been com- pletely elucidated. It is derived from riboflavin and involves five reactions, one of which, interestingly enough, seems to require oxygen.

Propionibacteria have already been known, for quite a long time, as sources of vitamin $B_{12}$ [20]. Many fermentative processes have been described, usually focussed on growing the bacteria to high cell densities. Varying the nutrient composition of the growth medium, in f.i. amino acid composition or mineral composition including cobalt-ions, usually, only affected $\mathrm{B}_{12}$-production when the growth yield of the Propionibacterium was affected. Two experimental findings lead to major improvements in the production yields of vitamin $B_{12}$ : (1) addition of the precursor dimethylbenzimidazole increased $\mathrm{B}_{12}$-production, and (2) aerobic incubation in the latter phase of fermentation resulted in increased $\mathrm{B}_{12}$-production [37]. The exact explanation for the aerobic stimulation of $\mathrm{B}_{12}$ production is currently not known. It could 
be that the addition of the adenosyl-moiety is an oxygen-dependent process. Another possibility is the stimulation of dimethylbenzimidazole-synthesis by oxygen. Using either or both of these strategies, production levels of 10 to $35 \mathrm{mg} \cdot \mathrm{L}^{-1}$ could be reached during fermentation of Propionibacterium in f.i. cheese whey as cheap growth medium [6].

A semi-continuous, large-scale, production process was recently described for Propionibacterium based on this knowledge [23]. It involves, first, an anaerobic growth phase in which most of the (dense) growth occurs and precursors such a precorrins and corbyrinic acid are synthesised. Then, in a second phase, the culture is lightly aerated and dimethylbenzimidazole is added. For efficiency, cells are transferred to a new vessel for the second phase, leaving the first vessel (partly) empty for filling with fresh growth medium and start of a new first phase, anaerobic fermentation. By removing $40 \%$ of the (anaerobic) culture in the first vessel and replacing it with fresh medium every $12 \mathrm{~h}$, a semi-continuous process was created, with a (almost) constant production during nine repeated fill-and-draw fermentations [23]. This process resulted in at least threefold more vitamin $\mathrm{B}_{12}$ production in comparison to the original, two-phase, batch cultivation.

\subsection{Folic acid}

Folic acid is an essential component in the human diet. It is involved, as cofactor, in many metabolic reactions, including the biosynthesis of the building blocks of DNA and RNA, the nucleotides. The daily recommended intake for an adult is $200 \mu \mathrm{g}$. For pregnant women a double dose is recommended, since folic acid is known to prevent neural-tube defect in newly borns [42]. Low folic acid in the diet is associated with high homocysteine levels in the blood and, subsequently, with coronary diseases $[8,9$,
30]. It is even reported to protect against some forms of cancer [2]. Folic acid is produced by different (green) plants (folium (latin) $=$ leaf) and by some microorganisms. Vegetables and dairy products are the main source of folic acid for humans.

"Folate" is a non-specific term referring to any folate compound with vitamin activity. The term folic acid is used for the chemically synthesised vitamin.

Folate is isolated from natural sources in many different forms. The basic structure of the molecule consists of a pteridine moiety, a $p$-aminobenzoic acid residue and one or more $\gamma$-linked L-glutamic acid residues. In the general metabolism, folates act as an acceptor and donor of C1-residues. This main biochemical function of folate is mediated by the $\mathrm{N}-5$ and $\mathrm{N}-10$ positions (Fig. 2) which carry methyl-, methynyl-, methylene-, formimino- or formyl residues. The pyrazine rings can be reduced to the so-called dihydro- and tetrahydro-form of the folate molecule. Finally, the poly- $\gamma$ L-glutamate tail can vary in length between 1 and 10. Folate is conspicuously absent in many food products and is considered an essential additive to the general diet. Folate is an essential cofactor in bacterial metabolism and, as such, will be present in most, if not all, bacteria. Folate is produced in many forms in nature: methylated, hydrated and containing various sizes of polyglutamate tails. Uptake of folate by auxotrophic bacteria and possibly also by human cells, however, is claimed to be restricted to specific folate molecules with polyglutamate tails of three moieties or less. Many bacteria are able to synthesize this cofactor by themselves from simple precursors, such as GTP, $p$-aminobenzoic acid and glutamate (Fig. 3), but some auxotrophic bacteria, including many lactic acid bacteria, have a strict growth requirement for folic acid.

Milk is a well-known source of folate. It contains between 20 and $50 \mu \mathrm{g} \cdot \mathrm{L}^{-1}$ folate and thus contributes significantly to the daily requirement of the average human. 


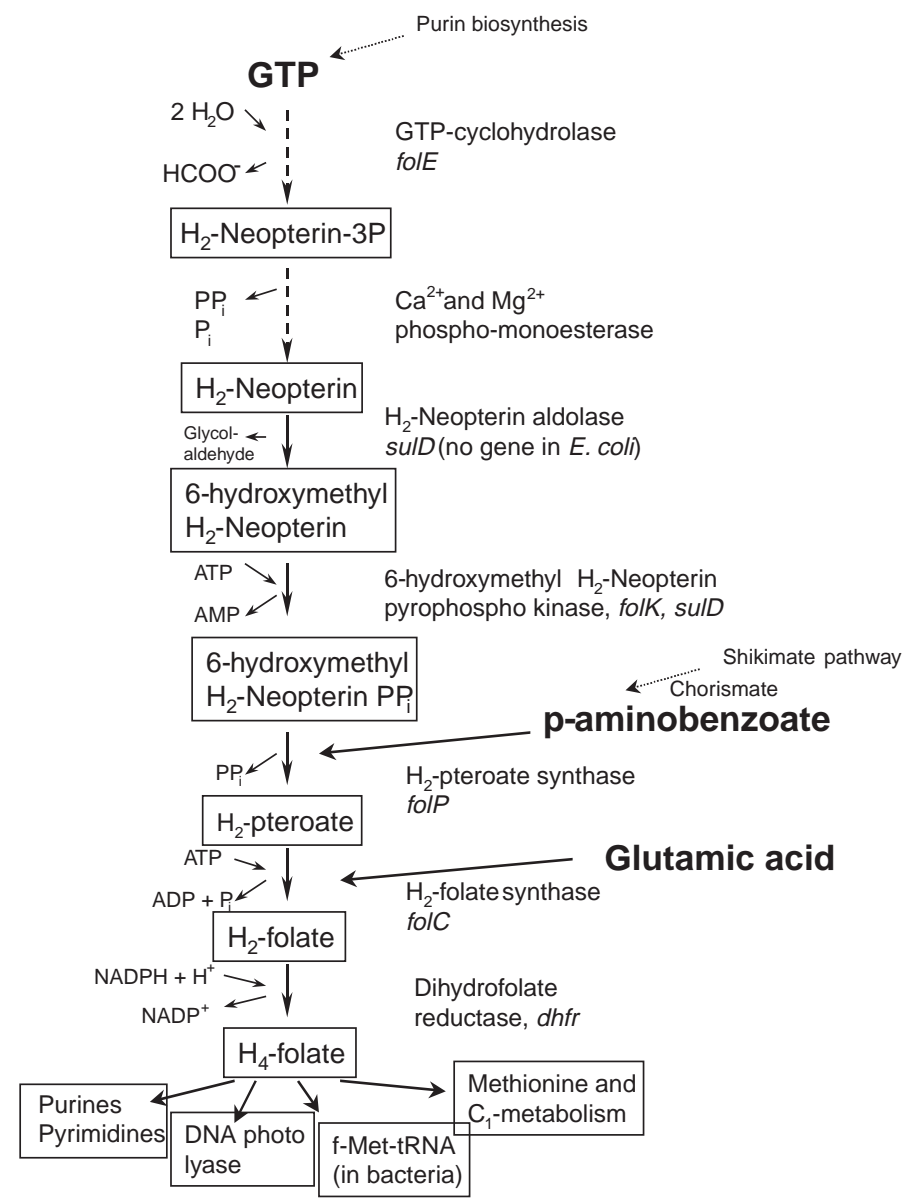

Figure 2. Pathway for biosynthesis of folate in lactic acid bacteria.

Fermented milk products, especially yoghurt, are reported to, sometimes, contain, even higher amounts of folate [1]. Up to $150 \mu \mathrm{g} \cdot \mathrm{L}^{-1}$ folate has been found in yoghurt. This high level is a direct result of the production of additional folate by the lactic acid bacteria in the yoghurt. Of the two lactic acid bacterial species in yoghurt, Lactobacillus bulgaricus and Streptococcus thermophilus, only the latter is reported to produce folate [34]. Recently, also some other food-grade bacteria were observed to produce folate during milk fermentation
[25]. Here we report on the folate production by different propionibacteria. Large differences can be found between different strains and different species. Interestingly, the levels produced are equally high or even higher than the well-known folate producer, Streptococcus thermophilus ([40], Tab. 1). Another striking observation is the difference in ability to excrete folate by the different propionibacteria. Some strains, clearly, retain all the folate intracellularly while in other strains almost complete excretion or leakage of the folate is observed. 


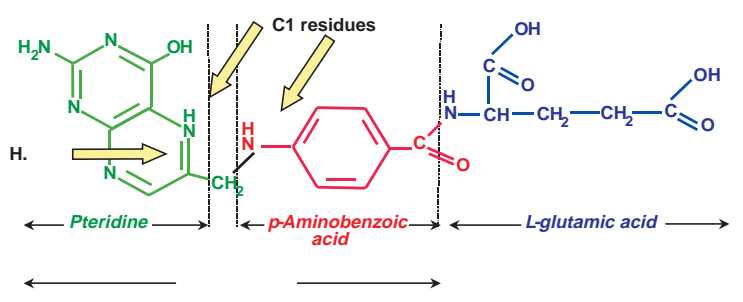

Figure 3. Molecular structure of folic acid (= pteroylmonoglutamic acid).

Table I. Screening for folate production in strains of different Propionibacterium species. Folate was analysed by the method of Horne and Patterson [22]. Negative values indicate folate utilisation from the medium.

\begin{tabular}{|c|c|c|c|c|}
\hline \multirow{2}{*}{ Species } & \multirow[t]{2}{*}{$\begin{array}{l}\text { Strain } \\
\text { NIZO }\end{array}$} & \multicolumn{3}{|c|}{$\begin{array}{l}\text { Net folate production } \\
\qquad\left(\mu \mathrm{g} \cdot \mathrm{L}^{-1}\right)\end{array}$} \\
\hline & & Intracellular & Extracellular & Total \\
\hline Propionibacterium thoenii & B361 & 28 & 8 & 36 \\
\hline Propionibacterium acidipropionici & B362 & 58 & -22 & 36 \\
\hline Propionibacterium jensenii & B364 & 51 & -11 & 40 \\
\hline Propionibacterium freudenreichii ssp. shermanii & B360 & 25 & 18 & 43 \\
\hline Propionibacterium freudenreichii ssp. shermanii & B363 & 82 & -20 & 61 \\
\hline Propionibacterium freudenreichii ssp. shermanii & B365 & 0 & 41 & 41 \\
\hline Propionibacterium freudenreichii ssp. shermanii & B367 & 73 & -3 & 70 \\
\hline Propionibacterium freudenreichii ssp. shermanii & B369 & 78 & -7 & 72 \\
\hline Propionibacterium freudenreichii ssp. shermanii & B370 & 24 & -6 & 17 \\
\hline Propionibacterium freudenreichii ssp. shermanii & B371 & 73 & -6 & 67 \\
\hline Propionibacterium freudenreichii ssp. shermanii & B372 & 79 & -14 & 64 \\
\hline Propionibacterium freudenreichii ssp. shermanii & B373 & 93 & -16 & 78 \\
\hline Propionibacterium sp. & B359 & 31 & -22 & 9 \\
\hline Propionibacterium sp. & B366 & 13 & 16 & 29 \\
\hline
\end{tabular}

This, presumably, is a result of the different forms of folate that are produced by these propionibacteria. Analysis of the molecular structure, such as the nature of the bound C1-moiety and the presence and length of the polyglutamate-tail, will definitely shed more light on this matter.

\section{ANTIMICROBIAL COMPOUNDS}

Fermentation of biological material by propionibacteria, generally, leads to increase in shelf life of the resulting food products. In some investigated cases, the protective effect has been attributed to the 
formation of organic acids $[3,10,13,31$, $39]$ and specifically propionic acid and acetic acid, or to the formation of bacteriocins $[14,16,27,29,35$, see also Holo et al. in this issue]. Many other reports have not specified the mechanism of protection but only show the importance of the propionibacteria being present. At the previous, 2nd, Symposium on Propionibacterium, Babuchowski and coworkers [3] reported increased shelf life of fermented vegetables via the action of propionibacteria, Suomalainen and Mayra-Makinen described the same effect in (fermented) dairy products and bakery products [41] and Merry and Davies presented improvement in silage production and stability by the addition of propionibacteria [28]. Figure 4 shows a typical example of experimental results that are obtained as a result of random screening for antifungal activity. In this case, of the 11 Propionibacterium strains tested from the culture collection at NIZO food research, all strains caused inhibition of the Aspergillus sp., while half of the strains also inhibited growth of 4 Penicillium strains tested. Of all other bacteria tested, yeasts, lactic acid bacteria and other food-grade bacteria, only a few Pediococcus strains showed similar antifungal activity. Some examples of specific protective effects by propionic acid fermentation are described below.

\subsection{Propionic acid}

Propionic acid is a commodity chemical with uses, amongst others, for grain preservation, as antifungal agent and as herbicide $[18,26]$. In the food industry, propionic acid and its salts are accepted as preservatives for industrial use in bread manufacture [41]. In these food products, especially fungi and Bacillus sp., are the targets for inhibition by this weak organic acid. The concentrations that are required for inhibition are between $0.1 \%$ and $5 \%$.

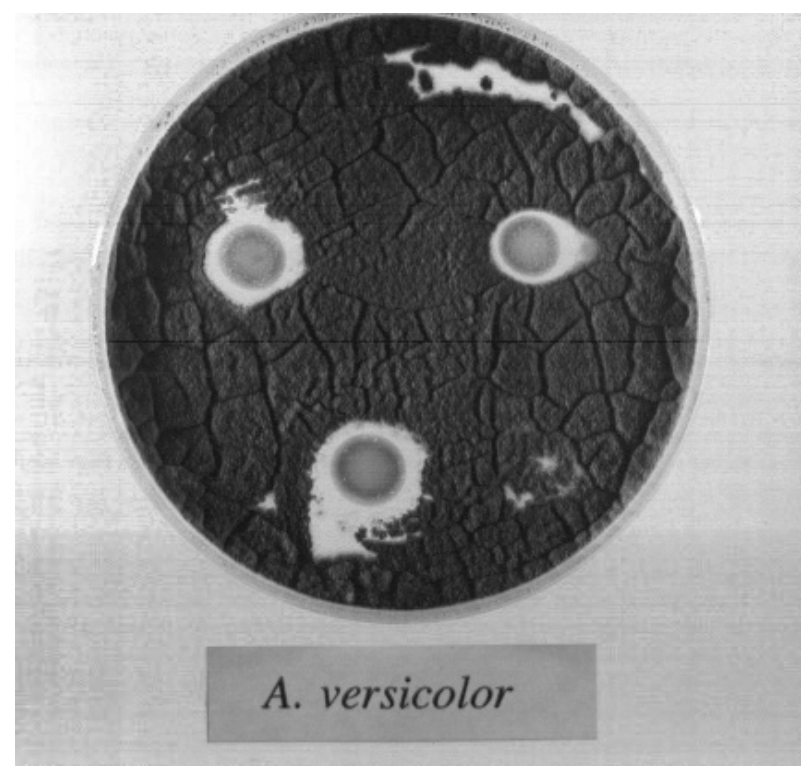

Figure 4. Inhibition of the fungus Aspergillus versicolor by growth of Propionibacterium freudenreichii ssp. shermanii NIZO strain B369. 
Propionibacterium spp. themselves are also very sensitive to propionic acid, and particularly to the undissociated form of this weak acid [17, 24]. Calculations based on reported propionic acid production levels under different growth conditions and external $\mathrm{pH}$ values of the medium, indicate that growth of the propionibacteria is already severely hampered by concentrations of undissociated propionic acid above $5 \mathrm{mmol} \cdot \mathrm{L}^{-1}$ and growth stops completely at $10 \mathrm{mmol} \cdot \mathrm{L}^{-1}[23,24]$.

The potential of propionibacteria for food preservation has been recognised commercially and already more than 10 years ago a new biopreservative, Microgard ${ }^{\mathrm{TM}}$, was launched on the market [10]. Its inhibitory action was based on a combination of inhibitory effects reported for propionibacteria, most notably propionic acid and bacteriocins.

\section{TREHALOSE}

Body-weight control is of major concern in our Western countries and obesity has been estimated to cost between 2 and $5 \%$ of total health-care expenses of various countries. New food products containing lowcalory sugars and/or fat replacers are in constant progression on the market in response to the consumer's request.

Trehalose is a well-known non-reducing disaccharide synthesized by a wide variety of organisms. It is only partially digested in humans, and therefore it is considered a dietetic sugar. It is also poorly metabolised by many other organisms, including lactic acid bacteria. The oral bacteria, Streptococcus mutans and Streptococcus salivarius, for instance, are not able to perform acidification with trehalose as only carbohydrate [32]. In comparative studies with human volunteers, mouth rinses with trehalose solutions led to significantly reduced acidification in plagues compared with rinsing with sucrose solutions. By feeding rats with trehalose-containing diets, instead of sucrose, almost complete suppression of dental decay (caries) was observed [32].

Other (biological) activities than can be attributed to trehalose are protection of proteins and whole cells against denaturation under different stress conditions such as heating, drying and freezing. The preserving and stabilising properties of trehalose on different biological systems have been widely demonstrated with different enzymes [4, 15], membranes [15], human cells [19], tissues [44] and organs [5]. In experimental biology, it has been observed that biological material is maintained in original, "fresh", state over extended periods of time in the presence of trehalose [12], which is especially relevant in the context of prolonged preservation of different kinds of food. More recently, it has been shown that trehalose has important stabilising effects on human proteins, preventing protein aggregation as well as formation of pathological conformational forms, and its application against illnesses, such as the Creutzfeld-Jakob disease has been disclosed [38]. Given the beneficial properties of trehalose, the development of food products in which trehalose is produced in situ at the expense of other sugars, such as lactose, fructose or glucose, is highly desirable.

As with many other microorganisms [7, 43], in Propionibacterium trehalose accumulation has been shown to occur as a result of different stress conditions, such as low temperature, high osmolarity and other adverse growth conditions [36]. Trehalose is formed from the glycolytic intermediate glucose 6-phosphate via glucose 1-phosphate, UDP-glucose, trehalose 6-phosphate to trehalose [11]. The enzymes that are specific for trehalose production are trehalose6-phosphate synthase and trehalose 6phosphate phosphatase. The intracellular concentrations that are reached vary enormously between different strains and are also strongly dependent on the growth conditions applied. In some fermentations 
using propionibacteria, high amounts of trehalose were found (F. Cardoso, P. Gaspar, A. Ramos, H. Santos, unpublished results). This demonstrates the actual potential of the use of propionibacteria for production of the low-calorie sugar trehalose in (fermented) foods.

\section{CONCLUSIONS}

Propionibacteria have been mentioned before in the scientific literature in relation to beneficial effects upon consumption by humans [33]. These so-called probiotic properties, however, are sometimes more suggestive than rock-solid, mostly due to uncertainty over the actual mechanism that is involved in providing the health-benefit. In this overview we have shown that propionibacteria can produce several components that actually contribute to the health-status of (fermented) foods. These components - vitamin $\mathrm{B}_{12}$ and folate as essential nutrients, propionic acid and bacteriocins as food preservatives and trehalose as low-calorie sugar and proteinstabiliser - can be formed through fermentation with selected propionibacteria, and, as such, can improve the nutritional value of fermented foods.

\section{ACKNOWLEDGEMENTS}

We thank S. van Schalkwijk and G. Rutten for performing the screening experiments. Part of this work was financially supported by the EU through contract QLK1-CT-2000-01376 (Nutra Cells, www.nutracells.com).

\section{REFERENCES}

[1] Alm L., Effect of fermentation on B-vitamin content of milk in Sweden, J. Dairy Sci. 65 (1980) 353-359.

[2] Ames B.N., Micronutrient deficiencies cause DNA damage and cancer, Food Sci. Agric. Chem. 1 (1999) 1-15.
[3] Babuchowski A., Laniewska-Moroz L., Warminska-Radyko I., Propionibacteria in fermented vegetables, Lait 79 (1999) 113-124.

[4] Baptista R.P., Cabral J.M., Melo E.P., Trehalose delays the reversible but not the irreversible thermal denaturation of cutinase, Biotechnol. Bioeng. 70 (2000) 699-703.

[5] Beattie G.M., Leibowitz G., Lopez A.D., Levine F., Hayek A., Protection from cell death in cultured human fetal pancreatic cells, Cell Transplant. 9 (2000) 431-438.

[6] Berry E.C., Bullerman L.B., Use of cheese whey for vitamin $B_{12}$ production, Appl. Microbiol. 14 (1966) 356-357.

[7] Boos W., Ehmann U., Forkl H., Klein W., Rimmele M., Postma P., Trehalose transport and metabolism in Escherichia coli, J. Bacteriol. 172 (1990) 3450-3461.

[8] Boushey C.J., Beresford A.A., Omenn G.S., Moltulsky A.G., A quantitative assessment of plasma homocysteine as a risk factor for vascular disease, J. Amer. Med. Assoc. 274 (1996) 1049-1057.

[9] Brattstrom L., Vitamins as homocysteine-lowering agents, J. Nutr. 126 (1996) 1276S-1280S.

[10] Daeschel M.A., Antimicrobial substances from lactic acid bacteria for use as food preservatives, Food Technol. 43 (1989) 164-167.

[11] Deborde C., Corre C., Rolin D.B., Nadal L., de Certaines J.D., Boyaval P., Trehalose biosynthesis in dairy Propionibacterium, J. Magn. Reson. Anal. 2 (1996) 297-304.

[12] de Carlo S., Adrian M., Kalin P., Mayer J.M., Dubochet J., Unexpected property of trehalose as observed by cryo-electron microscopy, J. Microsc. 196 (1999) 40-45.

[13] Doores S., Organic acids, in: Davidson P.M., Branen A.L. (Eds.) Antimicrobials in Foods, Marcel Dekker New York, USA, 1993, pp. 95-136.

[14] Faye T., Langsrud T., Nes I.F., Holo H., Biochemical and genetic characterization of propionicin $\mathrm{T} 1$, a new bacteriocin from Propionibacterium thoenii, Appl. Environ. Microbiol. 66 (2000) 4230-4236.

[15] Felix C.F., Moreira C.C., Oliveira M.S., SolaPenna M., Meyer-Fernandes J.R., Scofano H.M., Ferreira-Pereira A., Protection against thermal denaturation by trehalose on the plasma membrane $\mathrm{H}+$-ATPase from yeast. Synergetic effect between trehalose and phospholipid environment, Eur. J. Biochem. 266 (1999) 660-664.

[16] Grinstead D.A., Barefoot S.F., Jenseniin G., a heat-stable bacteriocin produced by Propionibacterium jensenii P126, Appl. Environ. Microbiol. 58 (1992) 215-220.

[17] Gu Z., Glatz B.A., Glatz C.E., Effects of propionic acid on propionibacteria fermentation, Enz. Microbiol. Technol. 22 (1998) 13-18. 
[18] Gu Z., Rickert D.A., Glatz B.A., Glatz C.E., Feasibility of propionic acid production by extractive fermentation, Lait 79 (1999) 137-148.

[19] Guo N., Puhlev I., Brown D.R., Mansbridge J., Levine F., Trehalose expression confers desiccation tolerance on human cells, Nat. Biotechnol. 18 (2000) 168-171.

[20] Hettinga D.H., Reinbold G.W., The propionic acid bacteria - A review, J. Milk Food Technol. 35 (1972) 295-301.

[21] Hollriegl V., Lamm L., Rowold J., Horig J., Renz P., Biosynthesis of vitamin $B_{12}$. Different pathways in some aerobic and anaerobic microorganisms, Arch. Microbiol. 132 (1982) 155-158.

[22] Horne D.W., Patterson D., Lactobacillus casei microbiological assay of folic acid derivatives in 96-well microtiter plates, Clin. Chem. 34 (1983) 2357-2359.

[23] Hunik J., Improved process for the production of vitamin $B_{12}$, Patent WO 00/37669.

[24] Jin Z., Yang S.-T., Extractive fermentation for enhanced propionic acid production from lactose by Propionibacterium acidipropionici, Biotechnol. Prog. 14 (1998) 457-465.

[25] Lin M.Y., Young C.M., Folate levels in cultures of lactic acid bacteria, Int. Dairy J. 10 (2000) 409-414.

[26] Luck H., Chemical preservation of food, Zent. bl. Bakteriol. Mikrobiol. Hyg. [B]. 180 (1985) 311-318.

[27] Lyon W.L., Glatz B.A., Isolation and purification of propionicin PLG-1, a bacteriocin produced by a strain of Propionibacterium thoenii, Appl. Environ. Microbiol. 59 (1993) 83-88.

[28] Merry R.J., Davies D.R., Propionibacteria and their role in the biological control of aerobic spoilage in silage, Lait 79 (1999) 149-164.

[29] Miescher S., Stierli M.P., Teuber M., Meile L., Propionicin SM1, a bacteriocin from Propionibacterium jensenii DF1: isolation and characterization of the protein and its gene, Syst. Appl. Microbiol. 23 (2000) 174-184.

[30] Morrison H.I., Schnaubel D., Desmeules M., Wigle D.T., Serum folate and risk of fatal coranary heart disease, J. Amer. Med. Assoc. 275 (1995) 1893-1896.

[31] Muller H.M., Thaler M., Propionic acid preservation of corn following inoculation with molds and yeasts, Arch. Tierernahr. 31(1981) 789-799.

[32] Neta T., Takada K., Hirasawa M., Lowcariogenicity of trehalose as a substrate, J. Dent. 28 (2000) 571-576.
[33] Perez Chaia A., Zarate G., Oliver G., The probiotic properties of propionibacteria, Lait 79 (1999) 175-185.

[34] Rao D.R., Reddy A.V., Pulusani S.R., Cornwell P.E., Biosynthesis and utilization of folic acid and vitamin $\mathrm{B}_{12}$ by lactic cultures in skim milk, J. Dairy Sci. 67 (1984) 1169-1174.

[35] Ratnam P., Barefoot, S.F., Prince L.D., Bodine A.B., McCaskill L.H., Partial purification and characterization of the bacteriocin produced by Propionibacterium jensenii B1264, Lait 79 (1999) 125-136.

[36] Rolin D.B., Girard F., de Certaines J.D., Boyaval P., ${ }^{13} \mathrm{C}$ NMR study of lactate metabolism in Propionibacterium freudenreichii ssp. shermanii, Appl. Microbiol. Biotechnol. 44 (1995) 210-217.

[37] Roth J.R., Lawrence J.G., Bobik T.A., Cobalamin (coenzyme $\mathrm{B}_{12}$ ): Synthesis and biological significance, Ann. Rev. Microbiol. 50 (1996) 137-181.

[38] Singer M.A., Lindquist S., Thermotolerance in Saccharomyces cerevisiae: the Yin and Yang of trehalose, Trends Biotechnol. 16 (1998) 460-468.

[39] Singh-Verma S.B., Application of propionic acid for preserving mixed feeding stuffs, industrially prepared, as well as cereals and maize. Results of microbiologic studies, Zent. bl. Bakteriol. Parasitenkd. Infektionskr. Hyg. 125 (1970) 100-111.

[40] Smid E.J., Starrenburg M.J.C., Mierau I., Sybesma W., Hugenholtz J., Increase of folate levels in fermented foods, Innov. Food Technol. 10 (2001) 13-15.

[41] Suomalainen T.J., Mayra-Makinen A.M., Propionic acid bacteria as protective cultures in fermented milks and breads, Lait 79 (1999) 165-174.

[42] Wald N., Prevention of neural tube defects. Results of the medical research council vitamin study, Lancet 338 (1991) 131-137.

[43] Welsh D.T., Reed R.H., Herbert R.A., The role of trehalose in the osmoadaptation of Escherichia coli NCIB 9484: interaction of trehalose, $\mathrm{K}^{+}$and glutamate during osmoadaptation in continuous culture, J. Gen. Microbiol. 137 (1991) 745-750.

[44] Wu S.F., Suzuki Y., Kitahara A.K., Wada H., Nishimura Y., Skin flap storage with intracellular and extracellular solutions containing trehalose, Ann. Plast. Surg. 43 (1999) 289-294 